\title{
19. $\mathrm{O}^{18}$ AND $\mathrm{C}^{13}$ CONTENTS OF CARBONATES FROM DEEP SEA DRILLING SITES IN THE BLACK SEA ${ }^{1}$
}

\author{
W.G. Deuser, Woods Hole Oceanographic Institution, Woods Hole, Massachusetts \\ E.T. Degens, Hamburg University, Hamburg, Germany \\ and \\ P. Stoffers, Heidelberg University, Heidelberg, Germany
}

\begin{abstract}
Carbonates from three Black Sea drilling sites (Leg 42B) were analyzed for their $\mathrm{O}^{18}$ and $\mathrm{C}^{13}$ contents. The series of 137 samples covers all major environmental stages from the upper Miocene to the present. The material includes detritus and authigenic calcites, aragonites, dolomites, and mangano-siderites. Oxygen isotopes appear to have undergone considerable post-depositional exchange, but carbon isotope data are generally in agreement with paleontological and sedimentological observations which indicate frequent changes in the depositional environment from fresh water to brackish to marine and vice versa since the upper Miocene.
\end{abstract}

\section{BACKGROUND INFORMATION}

Clayton and Degens (1959) first demonstrated the feasibility of distinguishing fresh-water and marine carbonates by means of stable isotope ratios. Freshwater carbonates are commonly enriched in $\mathrm{C}^{12}$ and $\mathrm{O}^{16}$ relative to their marine counterparts. However, the isotopic composition of a carbonate not only depends on the environment at the time of deposition, but also on isotopic exchange processes during diagenesis. Postdepositional exchange has a greater effect on oxygen than on carbon, often limiting the use of oxygen isotope ratios as environmental criteria to younger sediments. For carbon, exchange may not alter the original ratios in samples as old as Paleozoic (Degens and Epstein, 1962).

The modern Black Sea is a restricted marine environment. Marine organisms with a tolerance for low salinity dominate the population. Black Sea surface water is depleted in $\mathrm{O}^{18}$ relative to SMOW (Standard Mean Ocean Water). The extent of depletion is controlled by factors such as: (a) volume and location of river discharge, (b) amount of inflowing Mediterranean water, (c) surface currents, (d) climate, and (e) depth of halocline. This rather complex hydrography and its variation with time due to changes in any of those parameters make it impossible to interpret isotope ratios of Black Sea carbonates in terms of paleotemperatures. The data can be used, however, to identify general trends in the development of the Black Sea environment since the upper Miocene.

'Contribution No. 3847 from the Woods Hole Oceanographic Institution.

\section{ISOTOPE RECORD IN CARBONATES FROM THE HOLOCENE AND LATE GLACIAL}

Continental glaciers reached their maximum extent in the last ice age, approximately 18,000 years ago, at which time sea level was 85 meters lower than today (CLIMAP, 1976). The Black Sea was then a fresh-water lake, but subsequent influx of Mediterranean water gradually transformed the basin into the present restricted marine environment. Oxygen isotope analyses of carbonates from the abyssal plain $(\sim 2000 \mathrm{~m})$ reflect this development (Deuser, 1972). Typically marine $\left(\delta \mathrm{O}^{18}=0\right.$ to $\left.+2^{\circ} \% 0\right)$ and fresh-water values $\left(\delta \mathrm{O}^{18}=-6^{0} / 00\right)$ characterize sediments deposited most recently and before 10,000 years, respectively. Brackish samples have values in between (Figure 1). However, the fresh-water material was found to contain a substantial fraction, up to $80 \%$, of reworked Cretaceous and Tertiary marine limestones. Such material readily exchanges oxygen isotopes with fresh water, especially at slightly elevated temperatures. Consequently, $\delta \mathrm{O}^{18}$ values around $-6 \%$ are quite common for ancient marine carbonates which had post-depositional contact with fresh water. In contrast, carbon isotopes have little chance for post-depositional exchange and should thus better preserve the original environmental record.

The $\delta \mathrm{C}^{13}$ data for the top 6 meters of the abyssalplain sediments (Figure 1) show much less of the freshwater influence. Many of the measurements lie in the marine range, reflecting the substantial contribution of reworked marine carbonates during the lacustrine stage (Figure 1; core depth 1.5 to $6 \mathrm{~m}$ ).

A sample of special significance is the one at a core depth of $60 \mathrm{~cm}$ (Figure 1). The material, which is confined to a layer of about $50 \mu \mathrm{m}$ thickness, is entirely 
Core
Depth
(m)

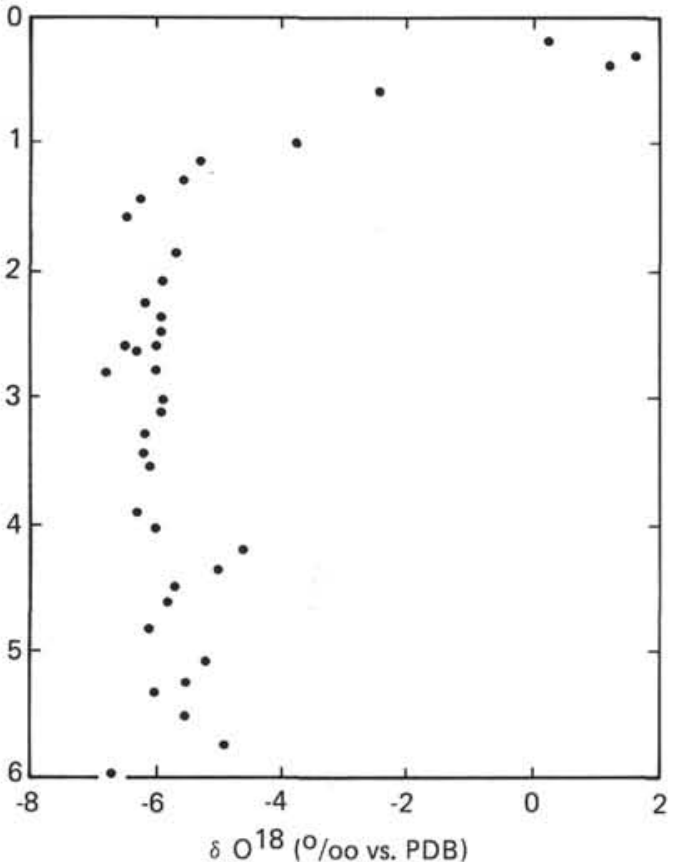

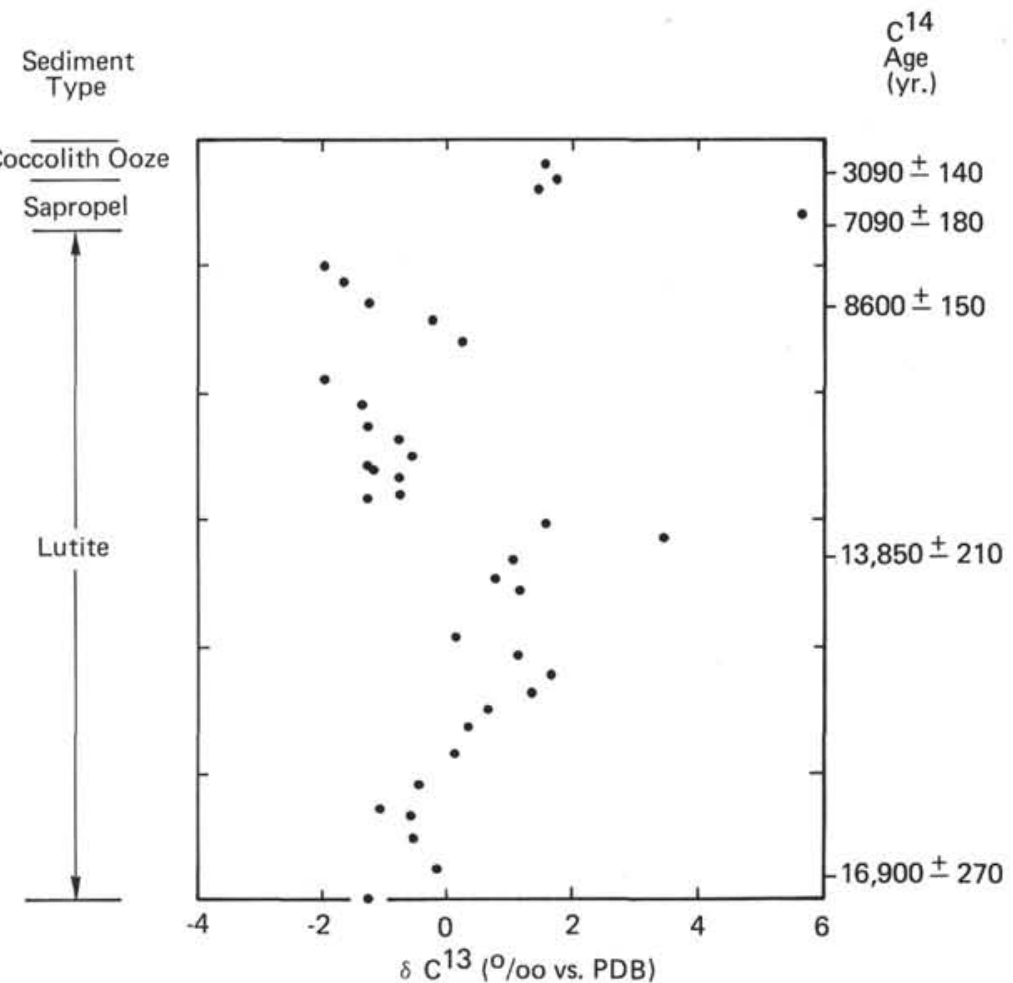

Figure 1. Profiles of $\delta O 18$ and $\delta C 13$ of carbonates in Black Sea central basin (Atlantis II Core $1474 \mathrm{~K}, 42^{\circ} 23.3^{\prime} \mathrm{N}$, $37^{\circ} 36.2^{\prime} E$ depth: $2117 \mathrm{~m}$ ). At the right margin are radiocarbon ages of organic matter (Deuser, 1972).

composed of aragonite grains, 10 to $40 \mu \mathrm{m}$ in size. The grains exhibit corrosional features. Similar aragonite layers, but without signs of corrosion on the grains, are common in sediments from the upper basin slope $(\sim 500 \mathrm{~m})$. Individual layers measure up to $2 \mathrm{~mm}$ in thickness. They were formed during the climatic optimum about 5 to 6 thousand years ago. At the time of aragonite precipitation the $\mathrm{O}_{2}-\mathrm{H}_{2} \mathrm{~S}$ interface very probably was at greater depth (Deuser, 1974). Preservation of the aragonite is better in shallow water, because the grains apparently start to dissolve upon entering the anoxic deep layer. The $\delta \mathrm{C}^{13}$ of the aragonite is $+5.7 \%$. This value is typical for calcium carbonate formed inorganically in seawater. At equilibrium there is about a 4 per mil fractionation between bicarbonate and carbonate, quite in contrast to carbonate formation by organisms such as mollusks, foraminifers, or coccoliths which, in the building of their shells, rely exclusively on organic template phenomena, a non-equilibrium process (Deuser and Degens, 1969; Degens, 1976).

\section{LEG 42B SAMPLES}

\section{Analytical Procedures}

Sediment samples were dried and ashed in a lowtemperature (plasma) asher for up to 30 minutes to remove organic matter. The carbon dioxide for isotopic analysis was then extracted by treating small portions of the material with $100 \% \mathrm{H}_{3} \mathrm{PO}_{4}$ in vacuo. Results are given in the $\delta$-notation, as per mil deviation from the PDB standard. Reproducibility of preparation and analysis is $\pm 0.1 \%$ for both carbon and oxygen.

\section{Hole 379A}

The top 10 to 20 meters of the site show frequent disturbances caused by drilling operation. Small patches of modern nannofossil ooze and sapropel are mixed in with stratigraphically older lutites. Below 20 meters the bedding is undisturbed. The sediments of the upper 450 meters are mainly terrigenous, except for sections of about 1 meter thickness of nannoplankton ooze, sapropel or micrite at about $0,100,220$, and 270 meters. Between 450 and 624 meters carbonate varves with a repeating pattern of up to $10 \mathrm{~cm}$ dominate the lithology. Lutites and occasional slumps are also present.

Based on the isotope data for modern Black Sea sediments (Deuser, 1972) summarized above, one might expect a similar pattern for the marine carbonates of the Eemian $(\sim 100 \mathrm{~m}$; Core 11$)$. The lithology is identical to that of the Recent sediments. Emiliania huxleyi is again the major coccolith species. However, the Eemian nannofossil ooze is $5 \%$ oo lower in $\delta \mathrm{O}^{18}$ and $1^{\circ} \%$ lower in $\delta \mathrm{C}^{13}$ (Figure 2 and Table 1).

The Eemian was a relatively warm period so that temperature effects may have lowered $\delta \mathrm{O}^{18}$ by perhaps $1 \%$ relative to the Recent deposits. The remaining $4 \%$ difference is most likely due to post-depositional exchange processes. The same appears to be the case with the Holsteinian marine sediments ( $220 \mathrm{~m}$; Core 25). It appears that the thin marine layers in an otherwise terrigenous facies did not retain their isotopic identity because the fine-grained coccoliths and micrites exchanged oxygen with the isotopically light interstitial water moving through the sediment. The similarity in both $\delta \mathrm{O}^{18}$ and $\delta \mathrm{C}^{13}$ between the lower part 


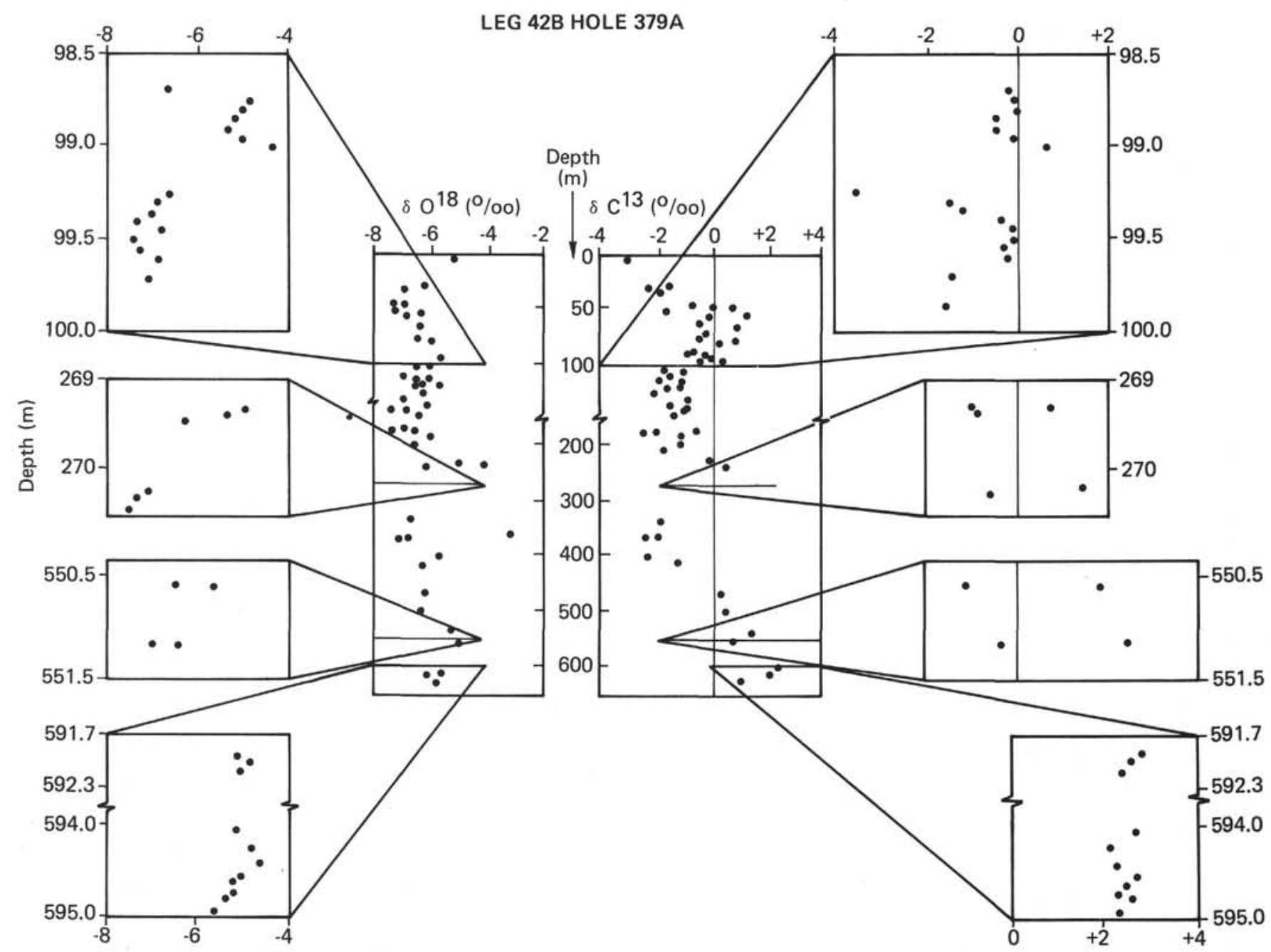

Figure 2. Profiles of $\delta O^{18}$ and $\delta C^{13}$ of carbonates in Black Sea sediments; Leg 42B, Hole 379A.

of core $1474 \mathrm{~K}$ and the upper 450 meters of Hole $379 \mathrm{~A}$ is evident from the plot of all analyses of Black Sea sediments shown in Figure 3.

The carbonate varves below 450 meters probably formed in a temperate to warm climate, but little information exists on the environment of deposition. The gross physical appearance of the varves suggests a shallow-water environment; the occurrence of Cyprideis littoralis and the absence of nektonic cypridopsine ostracodes suggest deposition in an alkaline playa lake (Benson, this volume). Bioturbate textures are common. The animals that produced the burrows have not been identified, but some polychaetes (Nereis; Reineck, 1958) have the requisite size and burrowing behavior (Degens et al., this volume).

Among the $\delta \mathrm{O}^{18}$ and $\delta \mathrm{C}^{13}$ values of the carbonate varves are some of the highest found at this site (Figure 2). Although marine conditions cannot be ruled out, a good analog among modern environments may be present in sediments of Lake Bonneville (Great Salt Lake, Utah). Those sediments are similarly varved. Eight calcite samples analyzed range in $\delta \mathrm{O}^{18}$ from -4.4 to $-7.3^{\circ} \%$ and have a mean $\delta \mathrm{C}^{13}$ of $3.15^{\circ} \%$ (Degens and Epstein, 1964).

\section{Hole 380A}

At this site a major unconformity occurs at about 320 meters. Sediments above this depth are largely terrigenous. It is estimated that the unconformity between the terrigenous and the chemical facies below represents a hiatus of 500,000 years (Stoffers et al., this volume).

The bulk of the carbonates below 320 meters appears to be authigenic. In the samples analyzed the amount of reworked carbonates is negligible. Calcareous nannoplankton is restricted to a few thin layers. The principal carbonate phases are chemically precipitated aragonite, high-magnesium calcite, calcite, dolomite, and mangano-siderite. The oldest material recovered at this site $(1074 \mathrm{~m}$ to about $900 \mathrm{~m})$ indicates shallow marine conditions during the late Pliocene. A dolomitic, pebbly mudstone with signs of subaerial exposure tops the section at about 880 meters depth. Following the deposition of the mudstone and continuing to the base of the Eburonian at 650 meters, the environment changed gradually from brackishmarine to fresh water (Stoffers et al., this volume). Based on available evidence, a lacustrine environment 
TABLE 1

Leg 42B, Hole 379A

\begin{tabular}{|c|c|c|c|c|}
\hline $\begin{array}{c}\text { Sample } \\
\text { (Interval in } \mathrm{cm} \text { ) }\end{array}$ & $\begin{array}{l}\text { Depth } \\
(\mathrm{m})\end{array}$ & $\begin{array}{l}\text { Carbonate } \\
\text { Mineralogy }\end{array}$ & $\begin{array}{l}\delta 0^{18} \\
(\% \circ)\end{array}$ & $\begin{array}{l}\delta \mathrm{C}^{13} \\
(\% \circ)\end{array}$ \\
\hline $1-1,70-72$ & 0.70 & $\mathrm{ca}$ & -6.64 & -0.64 \\
\hline $1-4,20-22$ & 4.70 & $\mathrm{ca}$ & -5.27 & -3.08 \\
\hline $4-3,10-12$ & 29.10 & $\mathrm{ca}$ & -6.18 & -1.60 \\
\hline $4-4,50-52$ & 31.00 & $\mathrm{ca}$ & -6.19 & -2.32 \\
\hline $4-5,66-68$ & 32.66 & $\mathrm{ca}$ & -6.97 & -1.92 \\
\hline $6-1,42-44$ & 45.42 & $\mathrm{ca}$ & -6.89 & -0.76 \\
\hline $6-2,42-44$ & 45.92 & $\mathrm{ca}$ & -7.33 & +0.90 \\
\hline $6-4,4-6$ & 49.54 & $\mathrm{ca}$ & -7.18 & -0.03 \\
\hline $6-5,126-128$ & 52.26 & $\mathrm{ca}$ & -6.39 & -1.65 \\
\hline $6-6,38-40$ & 52.88 & $\mathrm{ca}$ & -5.22 & +1.20 \\
\hline $7-2,1-3$ & 56.01 & $\mathrm{ca}$ & -6.82 & -0.16 \\
\hline $7-5,126-128$ & 61.76 & $\mathrm{ca}$ & -4.98 & -0.42 \\
\hline $8-1,14-15$ & 64.14 & $\mathrm{ca}$ & -6.38 & +0.86 \\
\hline $8-5,26-28$ & 70.26 & $\mathrm{ca}$ & -5.42 & -0.29 \\
\hline $9-2,20-22$ & 75.20 & $\mathrm{ca}$ & -6.40 & -0.41 \\
\hline $9-4,3-5$ & 78.03 & $\mathrm{ca}$ & -5.98 & +0.28 \\
\hline $9-5,136-138$ & 80.86 & $\mathrm{ca}$ & -5.39 & +0.83 \\
\hline $10-4,70-72$ & 88.20 & $\mathrm{ca}$ & -4.53 & -0.64 \\
\hline $10-5,23-25$ & 89.23 & $\mathrm{ca}$ & -5.46 & -0.88 \\
\hline $10-6,45-47$ & 90.95 & $\mathrm{ca}$ & -4.50 & -0.28 \\
\hline $11-2,71-74$ & 94.71 & $\mathrm{ca}$ & -4.72 & -0.04 \\
\hline $11-3,30-32$ & 95.80 & $\mathrm{ca}$ & -5.62 & -0.20 \\
\hline $11-4,50-52$ & 97.50 & $\mathrm{ca}$ & -6.45 & +0.32 \\
\hline $11-5,20-21$ & 98.70 & $\mathrm{ca}$ & -6.72 & -0.19 \\
\hline $11-5,25-26$ & 98.75 & $\mathrm{ca}$ & -4.96 & -0.11 \\
\hline $11-5,30-31$ & 98.80 & $\mathrm{ca}$ & -5.04 & -0.05 \\
\hline $11-5,35-36$ & 98.85 & $\mathrm{ca}$ & -5.25 & -0.46 \\
\hline $11-5,40-41$ & 98.90 & $\mathrm{ca}$ & -5.36 & -0.44 \\
\hline $11-5,45-46$ & 98.95 & $\mathrm{ca}$ & -5.03 & -0.07 \\
\hline $11-5,50-51$ & 99.00 & $\mathrm{ca}$ & -4.39 & +0.64 \\
\hline $11-5,75-76$ & 99.25 & $\mathrm{ca}$ & -6.64 & -3.53 \\
\hline $11-5,80-81$ & 99.30 & $\mathrm{ca}$ & -6.86 & -1.45 \\
\hline $11-5,85-86$ & 99.35 & $\mathrm{ca}$ & -6.97 & -1.20 \\
\hline $11-5,90-91$ & 99.40 & $\mathrm{ca}$ & -7.38 & -0.34 \\
\hline $11-5,95-96$ & 99.45 & $\mathrm{ca}$ & -6.84 & -0.09 \\
\hline $11-5,100-101$ & 99.50 & $\mathrm{ca}$ & -7.40 & -0.03 \\
\hline $11-5,105-106$ & 99.55 & $\mathrm{ca}$ & -7.31 & -0.24 \\
\hline $11-5,110-111$ & 99.60 & $\mathrm{ca}$ & -6.92 & -0.22 \\
\hline $11-5,120-121$ & 99.70 & $\mathrm{ca}$ & -7.11 & -1.40 \\
\hline $12-1,53-55$ & 102.53 & $\mathrm{ca}$ & -5.97 & -1.85 \\
\hline $12-2,24-26$ & 103. 74 & $\mathrm{ca}$ & -6.45 & -1.04 \\
\hline $13-1,25-27$ & 111.75 & $\mathrm{ca}$ & -6.89 & -1.52 \\
\hline $13-3,30-32$ & 114.80 & $\mathrm{ca}$ & -6.02 & -1.68 \\
\hline $13-4,24-26$ & 116.24 & $\mathrm{ca}$ & -6.41 & -1.85 \\
\hline $13-5,21-23$ & 117.71 & $\mathrm{ca}$ & -5.94 & -1.15 \\
\hline $13-6,5-7$ & 119.05 & $\mathrm{ca}$ & -6.39 & -1.65 \\
\hline $14-1,20-22$ & 121.20 & $\mathrm{ca}$ & -6.21 & -1.19 \\
\hline $14-4,16-18$ & 125.66 & $\mathrm{ca}$ & -6.21 & -2.01 \\
\hline $15-2,14-16$ & 132.14 & $\mathrm{ca}$ & -6.88 & -0.94 \\
\hline $15-5,7-9$ & 136.57 & $\mathrm{ca}$ & -6.20 & -1.47 \\
\hline $16-1,40-42$ & 140.40 & $\mathrm{ca}$ & -7.33 & -1.02 \\
\hline $16-2,15-17$ & 141.65 & $\mathrm{ca}$ & -6.89 & -1.07 \\
\hline $16-4,56-58$ & 145.06 & $\mathrm{ca}$ & -6.41 & -1.28 \\
\hline $19-1,130-132$ & 169.80 & $\mathrm{ca}$ & -6.87 & -2.05 \\
\hline $19-1,140-142$ & 169.90 & $\mathrm{ca}$ & -7.29 & -0.66 \\
\hline $19-2,17-19$ & 170.17 & $\mathrm{ca}$ & -6.61 & -2.42 \\
\hline $20-3,84-85$ & 181.84 & $\mathrm{ca}$ & -6.01 & -1.09 \\
\hline $21-6,13-14$ & 195.13 & $\mathrm{ca}$ & -6.59 & -1.17 \\
\hline $22-6,11-13$ & 204.61 & $\mathrm{ca}$ & -6.39 & -1.79 \\
\hline $25-3,30-32$ & 228.80 & $\mathrm{ca}$ & -5.08 & +0.14 \\
\hline $25-3,94-95$ & 229.44 & $\mathrm{ca}$ & -5.85 & +0.42 \\
\hline $25-3,134-135$ & 229.84 & $\mathrm{ca}$ & -4.13 & -0.17 \\
\hline $29-4,132$ & 269.32 & $\mathrm{ca}$ & -5.10 & -0.97 \\
\hline $29-4,136$ & 269.36 & $\mathrm{ca}$ & -5.45 & +0.73 \\
\hline $29-4,142$ & 269.42 & $\mathrm{ca}$ & -6.30 & -0.90 \\
\hline $29-5,69-70$ & 270.19 & $\mathrm{ca}$ & -7.15 & +1.46 \\
\hline $29-5,75-76$ & 270.25 & $\mathrm{ca}$ & -7.39 & -0.59 \\
\hline $29-5,90$ & 270.40 & $\mathrm{ca}$ & -7.44 & +1.85 \\
\hline
\end{tabular}

TABLE 1 - Continued

\begin{tabular}{|c|c|c|c|c|}
\hline $\begin{array}{c}\text { Sample } \\
\text { (Interval in } \mathrm{cm} \text { ) }\end{array}$ & $\begin{array}{l}\text { Depth } \\
\text { (m) }\end{array}$ & $\begin{array}{l}\text { Carbonate } \\
\text { Mineralogy }\end{array}$ & $\begin{array}{l}8 \mathrm{O}^{18} \\
(\% \circ)\end{array}$ & $\begin{array}{l}8 \mathrm{C}^{13} \\
(\%)\end{array}$ \\
\hline $36-4,73-75$ & 335.23 & $\mathrm{ca}$ & -6.68 & -1.92 \\
\hline $38-4,76-78$ & 354.76 & $\mathrm{ca}$ & -3.19 & +0.85 \\
\hline $39-5,25-27$ & 364.75 & $\mathrm{ca}$ & -7.02 & -2.01 \\
\hline $39-5,117-119$ & 365.67 & $\mathrm{ca}$ & -6.90 & -2.38 \\
\hline $43-5,92-94$ & 393.92 & $\mathrm{ca}$ & -5.71 & -2.36 \\
\hline $45-4,111-113$ & 411.61 & $\mathrm{ca}$ & -6.27 & -1.22 \\
\hline $51-2,26-28$ & 464.76 & $\mathrm{ca}$ & -6.14 & +0.31 \\
\hline $54-2,17-19$ & 493.17 & $\mathrm{ca}$ & -6.31 & +0.45 \\
\hline $58-4,89-93$ & 534.89 & $\mathrm{ca}$ & -5.27 & +1.45 \\
\hline $60-2,56-57$ & 550.56 & ca dark) & -6.54 & -1.02 \\
\hline $60-2,58-59$ & 550.58 & ca light) & -5.74 & +1.83 \\
\hline $60-2,119-120$ & 551.19 & ca light) & -7.03 & +2.43 \\
\hline $60-2,121-122$ & 551.21 & ca dark) & -6.49 & -0.29 \\
\hline $60-4,64-66$ & 553.64 & $\mathrm{ca}$ & -4.99 & +0.75 \\
\hline $65-4,91-92$ & 591.91 & $\mathrm{ca}$ & -5.17 & +2.81 \\
\hline $65-4,100-101$ & 592.00 & $\mathrm{ca}$ & -4.86 & +2.59 \\
\hline $65-4,109-110$ & 592.09 & $\mathrm{ca}$ & -5.09 & +2.42 \\
\hline $65-6,4-5$ & 594.04 & $\mathrm{ca}$ & -5.17 & +2.86 \\
\hline $65-6,24-25$ & 594.24 & $\mathrm{ca}$ & -4.84 & +2.13 \\
\hline $65-6,40-41$ & 594.40 & $\mathrm{ca}$ & -4.67 & +2.25 \\
\hline $65-6,54-55$ & 594.54 & $\mathrm{ca}$ & -5.14 & +2.77 \\
\hline $65-6,63-64$ & 594.63 & $\mathrm{ca}$ & -5.28 & +2.43 \\
\hline $65-6,71-72$ & 594.71 & $\mathrm{ca}$ & -5.32 & +2.39 \\
\hline $65-6,76-77$ & 594.76 & ca & -5.46 & +2.59 \\
\hline $65-6,94-95$ & 594.94 & $\mathrm{ca}$ & -5.62 & +2.27 \\
\hline $66-2,120-121$ & 598.70 & $\mathrm{ca}$ & -5.56 & +2.28 \\
\hline $67-2,129-130$ & 608.29 & ca & -5.99 & +2.13 \\
\hline $68-5,100-102$ & 622.00 & $\mathrm{ca}$ & -5.74 & +1.05 \\
\hline
\end{tabular}

${ }_{\text {a }}$ bbreviations for Tables $1-3: \mathrm{mc}=$ high-magnesium calcite;
ca = calcite; ar = aragonite; $s \mathrm{i}=$ siderite $;$ do = dolomite.

similar to that of the Lake Bonneville stage is assumed for the Eburonian. This continental-saline facies twice changed into a "classic" Scandinavian varve facies, at depths of 360 and 400 meters (Cores 4 and 8). A marine transgression tops the chemical facies at about 320 meters.

The isotope record agrees reasonably well with the interpretation based on sedimentological and paleontological observations (Figure 4; Table 2). The high $\delta \mathrm{C}^{13}$ values in most samples are characteristic of slowly formed inorganic precipitates. Environmental changes and different fractionations of the different carbonate phases are responsible for the apparent scatter in Figure 4. Post-depositional exchange of $0^{18}$ appears less severe than at Hole 379A because the carbonate grains are generally coarser and often consolidated into larger aggregates.

\section{Site 381}

A major unconformity between the younger terrigenous and the older chemical facies occurs at a depth of 180 meters. It is the same unconformity which appears at a depth of 320 meters at Site 380/380A, except that at Site 381 the hiatus covers a time span of almost 1.5 million years (Stoffers et al., this volume). A beach deposit with well-rounded sand grains and abundant shell fragments marks this horizon.

The oldest samples recovered from this site are of late Miocene age and of fresh-water origin (Schrader, this volume). During the Pliocene, a shallow marine environment developed which, between the late 


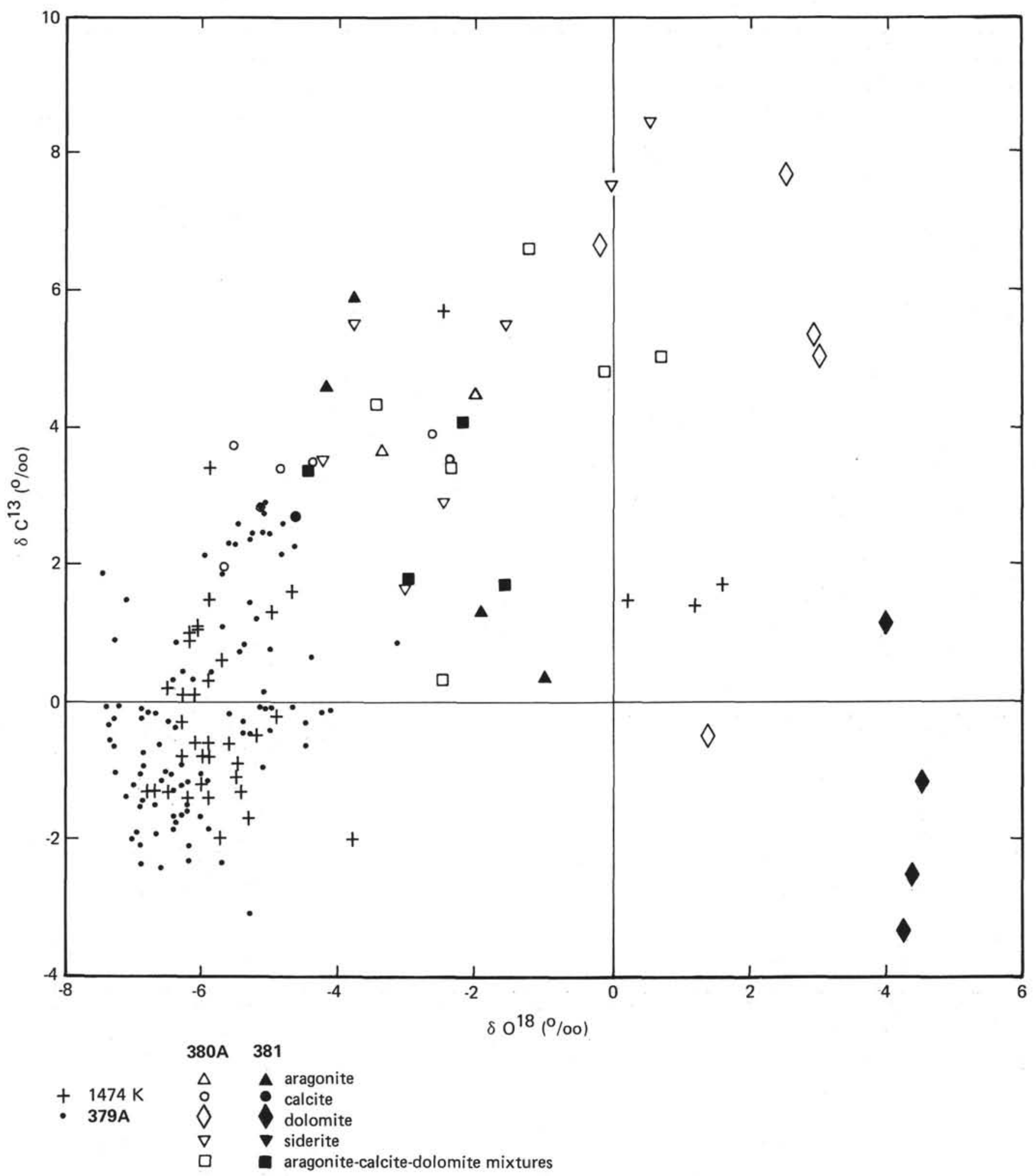

Figure 3. Plot of $\delta C^{13}$ versus $\delta O 18$ for all samples from Leg $42 B$ drilling sites and Atlantis II Core $1474 K$.

Pliocene and the Eburonian, changed from marine to brackish to fresh water (cf. Hole 380A). The massive dolomitic pebbly mud, which at Hole $380 \mathrm{~A}$ has a thickness of less than 20 meters, occupies almost 100 meters at Site 381 . However, the core recovery was poor. Intercalations of shell hash, beach sand, oolites, and disturbed mud sections suggest that during deposition of this dolomitic zone many transitions between a continental and a marine environment occurred, including extended periods of supratidal conditions (Stoffers et al., this volume).

The isotope data (Figure 5; Table 3) reflect these events to some extent. The shell hash above the major unconformity at 180 meters, and the one emplaced in 


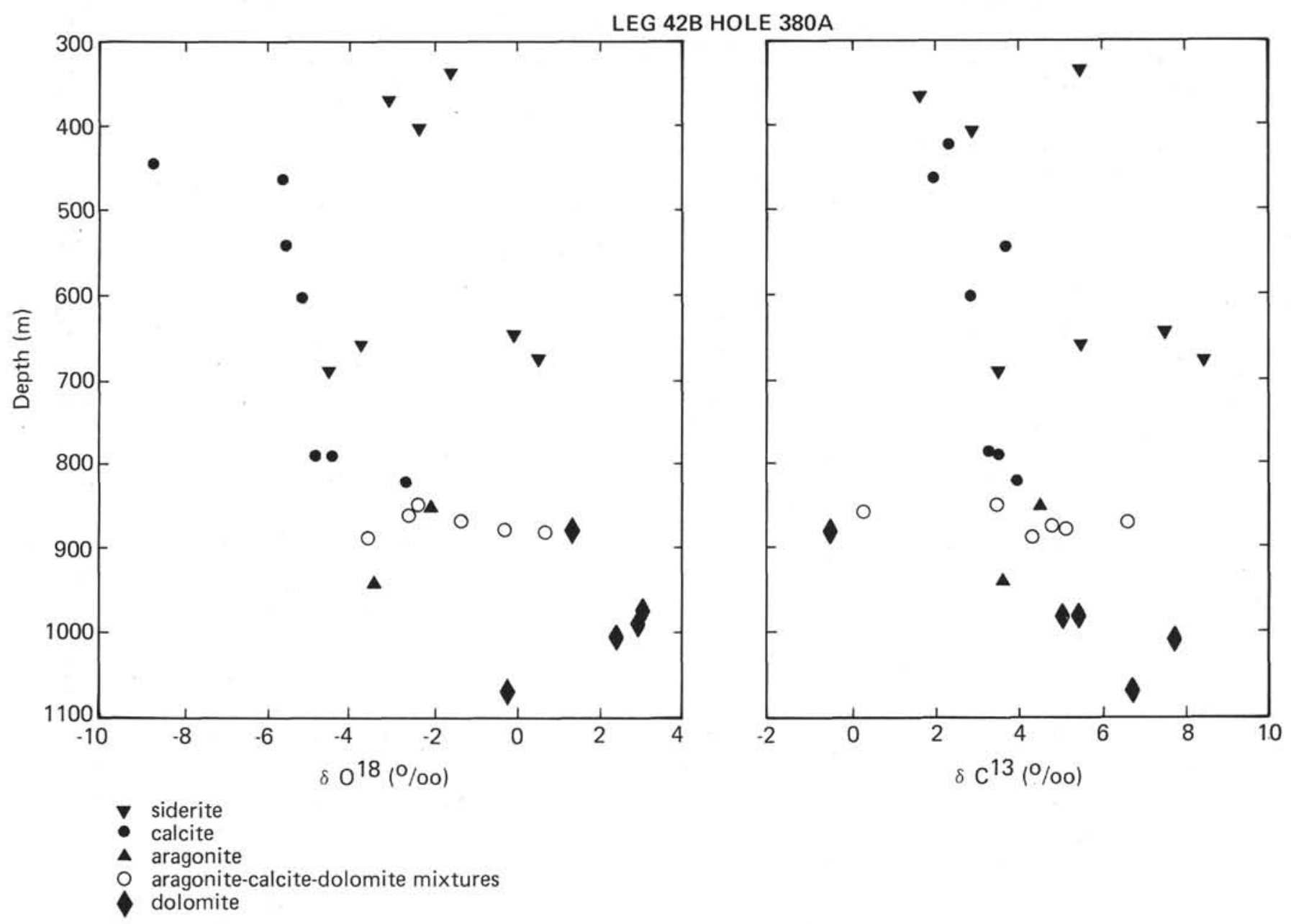

Figure 4. Profiles of $\delta O^{18}$ and $\delta C^{13}$ of carbonates in Black Sea sediments; Leg 42B, Hole $380 \mathrm{~A}$.

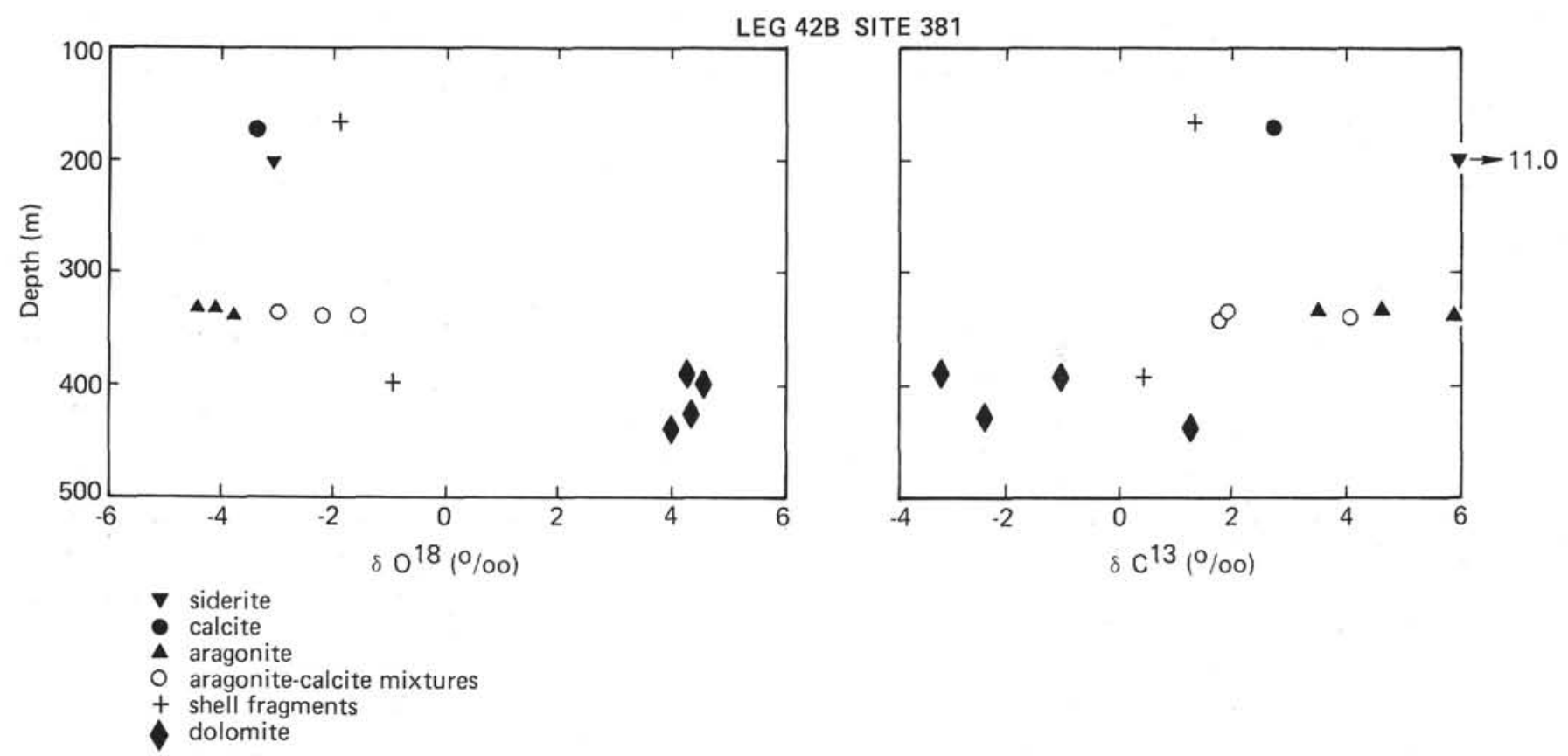

Figure 5. Profiles of $\delta O^{18}$ and $\delta C^{13}$ of carbonates in Black Sea sediments; Leg 42B, Site 381 . 
TABLE 2

Leg 42B, Hole 380A

\begin{tabular}{|c|c|c|c|c|}
\hline $\begin{array}{c}\text { Sample } \\
\text { (Interval in } \mathrm{cm} \text { ) }\end{array}$ & $\begin{array}{l}\text { Depth } \\
\text { (m) }\end{array}$ & $\begin{array}{c}\text { Carbonate } \\
\text { Mineralogy }{ }^{\mathrm{a}}\end{array}$ & $\begin{array}{l}\delta \mathrm{O}^{18} \\
(\% \circ)\end{array}$ & $\begin{array}{l}\delta \mathrm{C}^{13} \\
(\% \circ)\end{array}$ \\
\hline $1-3,111-113$ & 336.61 & si & -1.62 & +5.48 \\
\hline $4-4,122-123$ & 366.72 & si & -3.04 & +1.65 \\
\hline $8-5,148-150$ & 406.48 & si & -2.29 & +2.92 \\
\hline $12-4,86-88$ & 442.36 & $\mathrm{ca}$ & -8.71 & +2.36 \\
\hline $14-3,2-14$ & 459.02 & $\mathrm{ca}$ & -5.66 & +1.98 \\
\hline $22-6,68-70$ & 540.18 & $\mathrm{ca}$ & -5.56 & +3.76 \\
\hline $30-2,56-58$ & 600.56 & $\mathrm{ca}$ & -5.16 & +2.83 \\
\hline $34, \mathrm{CC}$ & 645.5 & si & -0.04 & +7.53 \\
\hline $36-2,80-82$ & 657.80 & si & -3.78 & +5.47 \\
\hline $37-6,134-136$ & 673.84 & si & +0.52 & +8.46 \\
\hline $39-3,102-104$ & 688.02 & $\mathrm{si}$ & -4.25 & +3.52 \\
\hline $49-5,42-44$ & 784.92 & $\mathrm{ca}$ & -4.83 & +3.41 \\
\hline $50-2,12-13$ & 789.62 & $\mathrm{ca}$ & -4.43 & +3.51 \\
\hline $53-2,92-94$ & 819.42 & $\mathrm{ca}$ & -2.66 & +3.95 \\
\hline $56-4,46-47$ & 850.46 & ar & -2.05 & +4.50 \\
\hline $56-4,56-58$ & 850.56 & ar82-ca6-mc12 & -2.40 & +3.54 \\
\hline $57-1,140-150$ & 856.40 & ar39-ca23-mc39 & -2.57 & +0.34 \\
\hline $58-3,104-106$ & 868.54 & do - ca & -1.35 & +6.61 \\
\hline $58, \mathrm{CC}$ & 873.5 & ca52-do48 & -0.15 & +4.81 \\
\hline $59-1,25-27$ & 874.25 & do & +1.38 & -0.54 \\
\hline $59-1,145-147$ & 875.45 & $\mathrm{ca} 22-\mathrm{do} 78$ & +0.74 & +5.08 \\
\hline $60-2,8-9$ & 885.08 & ar53-ca35-do12 & -3.52 & +4.31 \\
\hline $66-1,26-28$ & 940.76 & ar & -3.42 & +3.66 \\
\hline $69-5,15-20$ & 975.15 & do & +3.00 & +5.04 \\
\hline $70-3,100-104$ & 982.50 & do & +2.97 & +5.38 \\
\hline $72, \mathrm{CC}$ & 1006.5 & do & +2.42 & +7.72 \\
\hline $79-1,100-106$ & 1065.00 & do & -0.25 & +6.68 \\
\hline
\end{tabular}

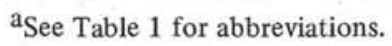

the dolomitic pebbly mud at 400 meters, have nearly normal marine values of both $\delta \mathrm{O}^{18}$ and $\delta \mathrm{C}^{13}$. The dolomites have uniformly high $\delta \mathrm{O}^{18}$. Their scattered $\delta \mathrm{C}^{13}$ values may be due to variable fresh-water input. The transition from marine to fresh-water conditions between 300 and 400 meters is indicated by the isotopic shifts of both the aragonites and the calcite-aragonite mixtures in the short interval between 330 and 340 meters.

\section{CONCLUSIONS}

The lithology and carbon and oxygen isotope ratios of carbonate material from DSDP Leg 42B suggest that since late Miocene times the Black Sea underwent several changes between marine and fresh-water conditions and had a continental-saline environment for extended periods. Late Miocene and Pliocene sediments were deposited in a shallow marine basin with occasional supratidal exposures. From late Pliocene to the end of the Cromerian, the environment was predominantly continental-saline, resembling in character the Eocene Green River Formation and the glacial and post-glacial stages of Lake Bonneville, Utah.

Starting with the Elsterian, fresh-water deposits seem to dominate the Pleistocene terrigenous sediment sequence. Brief intervals of marine deposition during the Holsteinian, Eemian, and following the Holocene climatic optimum, can be recognized.

Post-depositional exchange processes lowered the $\mathrm{O}^{18}$ content of carbonates but had little effect on $\mathrm{C}^{13}$
TABLE 3

Leg 42B, Site 381

\begin{tabular}{llllr}
\hline $\begin{array}{c}\text { Sample } \\
\text { (Interval in cm) }\end{array}$ & $\begin{array}{c}\text { Depth } \\
(\mathrm{m})\end{array}$ & $\begin{array}{l}\text { Carbonate } \\
\text { Mineralogy }\end{array}$ & $\begin{array}{l}\delta \mathrm{O}^{18} \\
(\%)\end{array}$ & $\begin{array}{r}\delta \mathrm{C}^{13} \\
(\%)\end{array}$ \\
\hline $18-2$ & & shell hash (ar) & -1.93 & +1.31 \\
$19-1,20-22$ & 171.20 & ca & -4.66 & +2.69 \\
$23-4,90-92$ & 204.90 & si & -3.06 & +11.03 \\
$37-1,85-87$ & 333.35 & ar93-ca7 & -4.42 & +3.45 \\
$37-1,123-125$ & 333.73 & ar & -4.19 & +4.60 \\
$37-2,110-112$ & 335.10 & ar22-ca44-mc33 & -2.99 & +1.83 \\
$37-5,45-47$ & 338.95 & ar & -3.78 & +5.91 \\
$37-5,82-84$ & 339.32 & ca25-mc75 & -1.60 & +1.73 \\
$37-5,116-118$ & 339.66 & ar70-ca13-mc17 & -2.26 & +4.08 \\
42, CC & 389.5 & do & +4.24 & -3.23 \\
$43-2,110-112$ & 392.10 & shell hash (ar) & -0.99 & +0.36 \\
$43-2,142-145$ & 392.42 & do & +4.52 & -1.09 \\
46, CC & 427.5 & do & +4.35 & -2.47 \\
47, CC & 437.0 & do & +3.98 & +1.17 \\
\hline
\end{tabular}

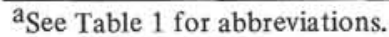

contents. The degree of exchange is not only a function of time and core depth (temperature), but depends also on grain size, mineralogy, permeability of strata, and stratigraphic position.

\section{ACKNOWLEDGMENTS}

We are indebted to Edith Ross and Lee Waterman for their assistance. This work was supported in part by Grant OCE7306586 from the National Science Foundation.

\section{REFERENCES}

Clayton, R.N. and Degens, E.T., 1959. Use of carbon isotope analyses of carbonates for differentiating fresh-water and marine sediments: Am. Assoc. Petrol. Geol. Bull., v. 43, p. $890-897$.

CLIMAP, 1976. The surface of the ice-age earth: Science, v. 191, p. $1131-1137$.

Degens, E.T., 1976. Molecular mechanisms of carbonate, phosphate, and silica deposition in the living cell: BerlinHeidelberg-New York, (Springer-Verlag), p. 112.

Degens, E.T. and Epstein, S., 1962. Relationship between $\mathrm{O}^{18} / \mathrm{O}^{16}$ ratios in coexisting carbonates, cherts, and diatomites: Am. Assoc. Petrol. Geol. Bull., v. 45, p. 534542.

1964. Oxygen and carbon isotope ratios in coexisting calcites and dolomites from recent and ancient sediments: Geochim. Cosmochim. Acta, v. 28, p. 23-44.

Deuser, W.G., 1972. Late Pleistocene and Holocene history of the Black Sea as indicated by stable-isotope studies: J. Geophys. Res., v. 77, p. 1071-1077.

1974. Evolution of anoxic conditions in Black Sea during Holocene: Am. Assoc. Petrol. Geol. Mem., v. 20, p. $133-136$

Deuser, W.G. and Degens, E.T., 1969. $\mathrm{O}^{18} / \mathrm{O}^{16}$ and $\mathrm{C}^{13} / \mathrm{C}^{12}$ ratios of fossils from the hot-brine deep area of the central Red Sea. In Degens, E.T. and Ross, D.A. (Eds.), Hot brines and recent heavy metal deposits in the Red Sea: New York (Springer-Verlag), p. 336-347.

Reineck, H.E., 1958. Wühlbau-Gefüge in Abhängigkeit von Sediment-Umlagerungen: Senckenb. Lethaéa, v. 39, p. 123. 